\title{
STUDY OF ELECTROGENIC PROPERTIES OF MICROFLORA OF MUD MASSES OBTAINED FROM VARIOUS BIOTYPES
}

\author{
Tjurin-Kuzmin A.Ju., Ilyin V.K., Korshunov D.V., Punegova A.V., Suprunova Ju.V.
}

\begin{abstract}
Microbial fuel cells (MFC) are an environmentally friendly way of generating electricity, which is often accompanied by the decomposition of organic waste. A common problem for these devices is the low power generated by the electric current. In nature, the decomposition of organic waste, coupled with oxidation-reduction reactions, i.e. the transfer of electrons and protons formed during the decomposition is carried out by microbial communities, which, in their optimal state for this process, are called active sludge (AS). A mature active sludge consists of a so-called flocculium - round formations in the size from 30 to 100 and more microns, inside of which microorganisms carrying out various reactions of decomposition of organic substances are contained. It is easy to see that the MFC design is topologically similar to the active sludge flocculant. We tried to check how the presence of microorganisms in the water chamber affects the productivity of the MFC by filling the anode and cathode chambers with the same sludge mixture, and the test cells were shaken on a shaker to create favorable conditions for the formation of microbial communities. The active sludge cell in both chambers shaken on the shaker, over time, generated the highest voltage in the external circuit as compared to the control samples. The obtained data confirm the legitimacy of the assimilation of MFC flocculine AS. The evolution of the microbial community of the silt mixture in two directions - in the aerobic and anaerobic MFC chambers - apparently leads to the formation of two different communities mutually complementing each other as part of the MFC and improving the operation of the MFC, subject to additional dynamic provision (shaking). The effect of the addition of peptone to the anode chamber on the productivity of MFC was also investigated. The periodic addition of peptone significantly increased the output power of the MFC cell. Apparently, substrates of protein nature, representing a nutrient medium for electrogenic bacteria, can be used to stimulate the electrogenic activity of the microflora of late anaerobic silt.
\end{abstract}

Key words: microbial fuel cells, biofuel elements, activated sludge, flocculum, nitrate respiration

\section{INTRODUCTION}

The use of microbial fuel cells (MFC) is an environmentally friendly way of generating electricity, reproducing a process that naturally flows on the Earth [1,2]. The MFC test during the flight of the Foton- $4 \mathrm{~m}$ satellite showed that this process is also able to occur in space, in a state of weightlessness. However, the electric current produced at this time is still small, which encourages us to look for ways to increase the efficiency of MFC.

In natural conditions, the decomposition of organic waste, coupled with oxidation-reduction reactions, i.e. the transfer of electrons and protons formed during the decomposition is carried out by microbial communities, which, in their optimal state for this process, are called active sludge (AS). AS is a structured system consisting of bacteria of different species, which does not form immediately, but ripens in the process of functioning under certain conditions.

Mature AS consists of floccules - rounded formations in the size from 30 to 100 and more microns, inside which there are mainly microaerophilic and anaerobic bacteria - the main converters of organic compounds, and outside aerobic, which complete the oxidation stages of decomposition products. The outer and inner layers are connected by structures that transport the products formed during decomposition, including electrons and protons [3].

The traditional design of the MFC includes an anaerobic - "microbial" chamber with microbes present in it, and an aerobic chamber - an "aqueous" chamber containing water. Both chambers contain electrodes electrically connected to each other through a payload, and the electrical circuit closes through a proton-permeable membrane separating chambers.

It is easy to see that the MFC design is topologically similar to the AS flocculature, with the difference that the connection of electrons and protons with oxygen takes place in the water chamber without the participation of microorganisms.

The purpose of the work was to determine how the presence of microorganisms in the water chamber and the periodic addition of peptone to the anode chamber will affect the productivity of the MFC.

\section{Objectives of work:}

1) To evaluate the effectiveness of continuous shaking as a biotechnological method of increasing the output power of a microbial fuel cell.

2) Confirm or disprove the likeness of the MFC to the active sludge flocculum. 
3) To investigate the microflora of the anode and cathode chambers of the MFC.

4) To estimate the effect of adding a solution of peptone to the output power of MFC.

As mentioned, maturation of AS occurs when a number of conditions are fulfilled [3], the main ones of which are:

1) dynamic provision conditions, i.e. transfer of nutrients and products of their decomposition, as well as mechanical effects on AS.

2) food conditions, i.e. the inflow of nutrients corresponding to the possibilities of the system for their processing.

3 ) the non-exceeding of the threshold level of toxic substances almost always present in sewage.

In the event that one of the above conditions is not met, the AS is not formed, with a lack of dynamic supply or nutrition, the bacteria enter into a "waiting" mode of favorable conditions, forming spore forms, etc., such a sludge Condition is usually called a mud mixture.

When working with MFC, condition 3) is satisfied by the experimenter. Condition 2) turns out to be uncritical when using AS. (Unlike the use of "pure cultures" of microorganisms that require special feeding, AS is able to consume organic substances that are part of its own composition, and can work in MFC for several years). Condition 1) in the MFC is performed only partially, ensuring the flow of electrons from the "microbial" chamber to the "water" chamber through the wires, and the transition of the protons through the proton-conducting membrane by diffusion. A priori, it was unclear whether such a dynamic provision is sufficient for the optimal operation of the MFC.

Under the maturation of the floccula, which, apparently, corresponds to the output of the MFC at the optimal level of functioning, it is possible to assume a change in the ratio of the bacterial species and the creation of metabolic transfer structures between them (or between the bacteria and the surface of the electrodes and the membrane).

Assuming a similar course of events, we filled the same mixture of silt and microbial and water chambers in two cells of the MFC. Controlled by them were MFC cells filled in a standard way, i.e. the silt mixture was placed only in the microbial chamber, and water was in the water chamber. One pair of cells (control-experiment) was immovable on a laboratory table, and the other pair was placed on a shaker with moderate shaking.

The effect on the output power of the cell adding a solution of peptone to the anode chamber was also estimated.

\section{MATERIALS AND METHODS}

Cells made of polypropylene in the form of two concentric vessels were used, of which a closed inner volume of $280 \mathrm{ml}$ was a microbial chamber, a membrane of the MK-40 type (Russia) with an area of $8 \mathrm{~cm}^{2}$ was fixed in its bottom, Volume $300 \mathrm{ml}$, was opened from the top for air access and played the role of a water chamber. The electrode of the microbial chamber was made of metallized carboncoated graphite and had an area of $62 \mathrm{~cm}^{2}$ (without taking into account the microstructure of the surface), the electrode of the water chamber was made of smooth graphite and had an area of $20 \mathrm{~cm}^{2}$. The electrodes were connected through a load of $150 \mathrm{kOm}$.

The sludge mixture was taken at the Kuriana Wastewater Treatment Plant in Moscow more than 10 years ago. All this time it was stored in a closed aluminum can at room temperature without additional influences.

Characteristics of the sludge mixture:

The dose of silt by volume is $850 \mathrm{ml}$.

The concentration of sludge is $16 \mathrm{~g} / 1$.

The sludge index is $53 \mathrm{ml} / \mathrm{g}$.

The transparency of the surface liquid is $>30 \mathrm{~cm}$.

To describe the sludge mass, the terms and methods described by O. Nikitina in her book "Bioestimation" [3] were used. Sediment concentration refers to the concentration (dose) of the sludge mass by weight. Filtered on a paper filter, a slurry of a certain volume of sludge was dried at $95^{\circ} \mathrm{C}$ for 2 hours (after making sure that the weight does not change with further drying). Transparency was determined by the height of the column of liquid, through which it was still possible to read the standard text of the book (10-12 Times New Roman).

Prior to loading into the MFC, the mixture was mixed with a scoop to a uniform state. Viewing of this mixture under a microscope did not reveal microorganisms in the stage of active vital activity, however, when this silt mass was placed in the conditions of dynamic provision, for example, with the possibility of removing protons and electrons formed in the process of metabolism (as in the MFC conditions), the vital processes became more active. The repeated use of this sludge mixture to fill the MFC has shown good reproducibility of the results.

The silt mixture to which the peptone solution was added was taken from the Makedonka River (Bykovo settlement, Ramensky district). In the anode chambers of the MFC, the sludge mass was placed, diluting with distilled water in a ratio of $1: 10$. The initial volume of sludge was thus $28 \mathrm{ml}$. The dry 
peptone was diluted with distilled water in a ratio of 4 g peptone per $100 \mathrm{ml}$ water. The resulting solution was added to the anode chamber of MTB 2 times a week in a volume of $4 \mathrm{ml}$. Also 2 times a week, $4 \mathrm{ml}$ samples were taken from the anode chamber of the MFC, some of which were analyzed on a photometer.

Studies of the microflora of MFC were carried out by traditional methods. "Sowing" was performed on the following media: LB agar, TSA and Wilkins medium for anaerobic bacteria. The cultures were incubated at $37^{\circ} \mathrm{C}$. Anaerobic conditions were achieved through the use of "Gazpacks". The resulting colonies were microscopized and, subsequently, were determined on a Bruker Daltonik MALDI Biotyper analyzer (Bruker, USA). The culture was considered identified when the appearance of the colonies and the morphology of the cells coincided with the analyzer data.

\section{RESULTS}

Although immediately after filling the cell "experiment on the shaker" gave a smaller indication, 26 days later she overtook the control, and then overtook and began to steadily exceed "control on the shaker" by $200 \mathrm{mV}$ (Fig. 1).

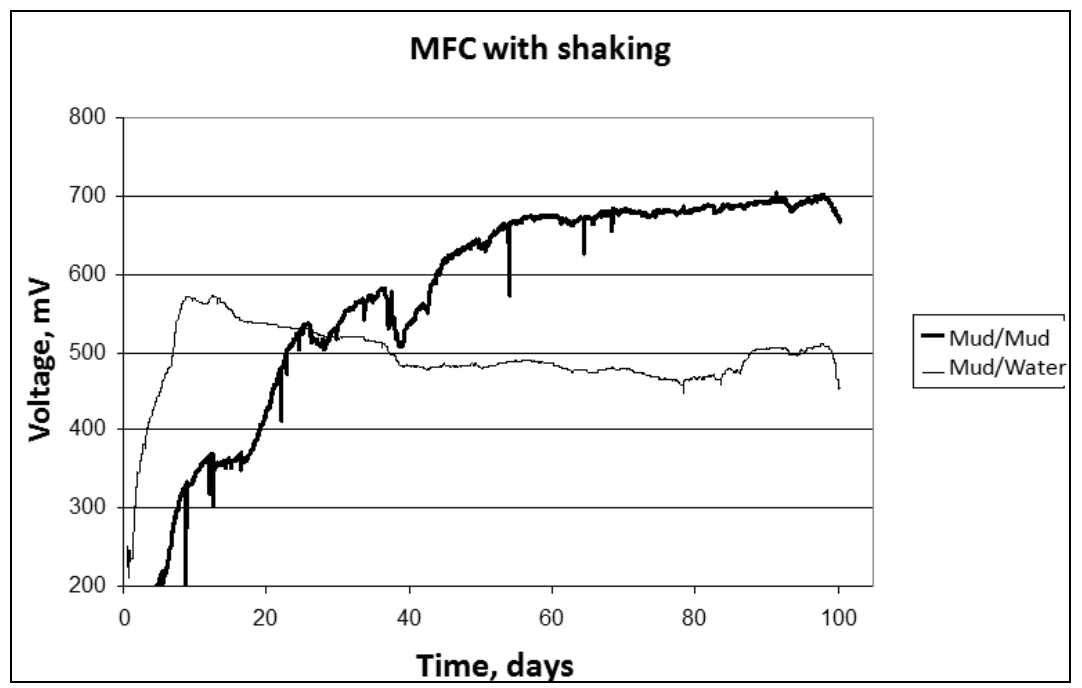

Fig. 1. Dynamics of the voltage variation in the outer circuit of MFC cells shaken on a shaker

Without additional shaking, the "experiment on the table" cell did not catch up with the control, and remained below the "control on the table" by $200 \mathrm{mV}$ (Fig. 2). At the same time, the region of the silt mixture around the electrode in the water chamber had a slightly different color as compared with the silt lying closer to the surface of the water, which is probably due to a different oxygenation of the mud.

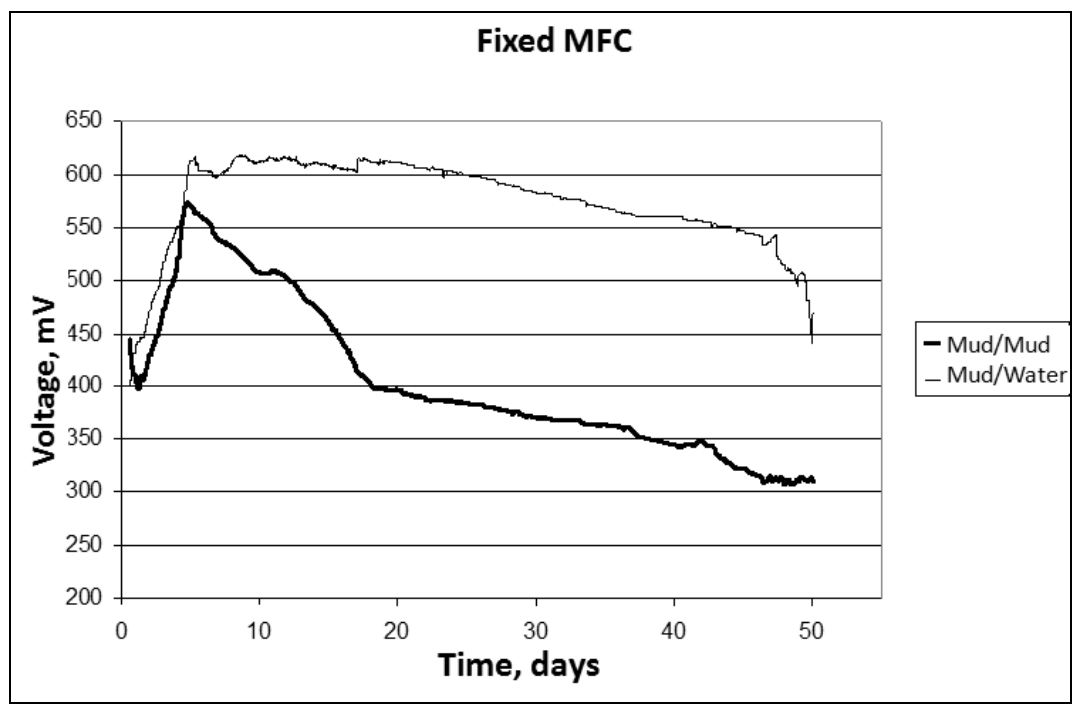

Fig. 2. Dynamics of voltage variation in the external circuit of fixed cells of MFC 
The cell "experiment on the shaker" was observed for more than two years (adding water to the water chamber as it evaporated). During this time, the cell readings remained at $700 \pm 30 \mathrm{mV}$. At autopsies (for sampling), the readings were restored after 0.5 - 1 days. After 2 years and 3 months after the start of the experiment, the cell was opened to determine the characteristics of the sludge. The sludge concentration decreased to $11.7 \mathrm{~g} / 1$.

To test the contribution of bacteria to the generation of electric current in the cells of the MFC, an experiment was performed with an autoclaved active silt, the results of which are shown in Fig. 3.

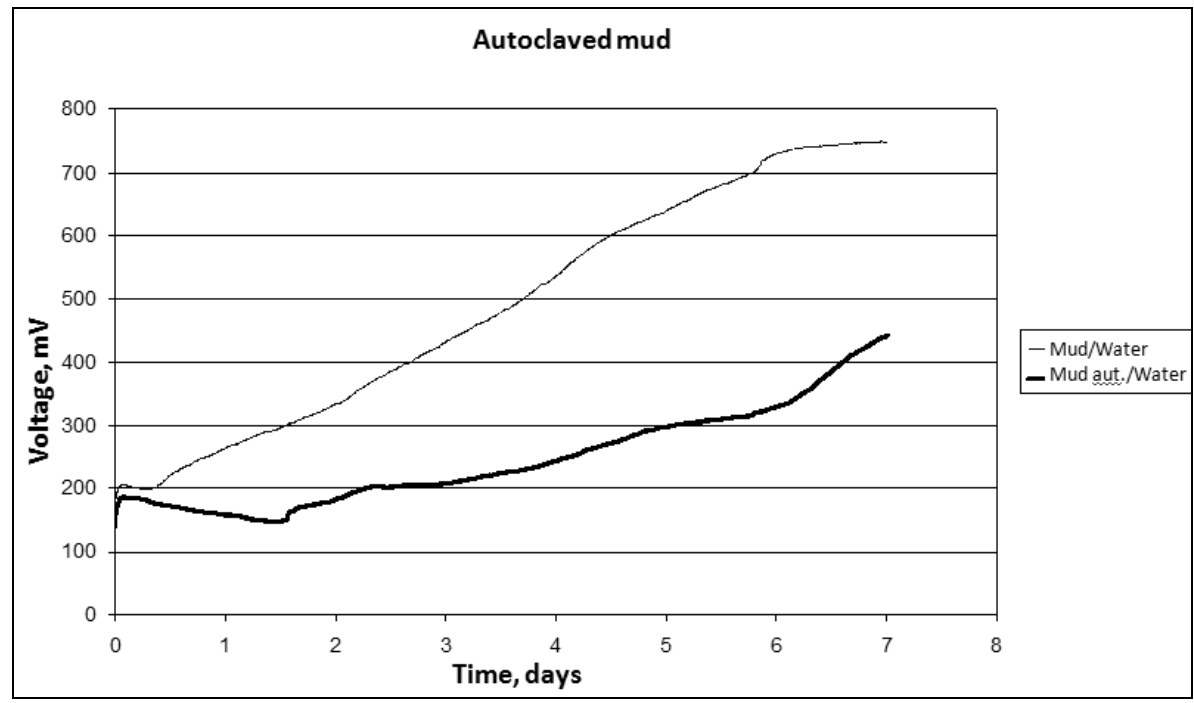

Fig. 3. Dynamics of voltage variation in the external circuit of fixed cells of MFC containing autoclaved mud

Autoclaved sludge showed a slight increase in voltage compared to the control sample. A week later, the control sample generated $700 \mathrm{mV}$ in the external circuit, while the autoclaved sludge generated $400 \mathrm{mV}$. The fact that the initially sterile environment of the experimental MFC was nevertheless able to increase the voltage in the external circuit can be explained by contamination of the anode chamber of the experimental MFC. Those who enter the sterile sludge bacteria (during the refueling procedure or from the external environment during the experiment) could provide an increase in voltage that is half that of the original community.

The list of bacteria found in the cells of the MFC is presented in Table 1.

Table 1. Comparative characteristics of metabolic peculiarities in bacteria isolated from the cell of a microbial fuel cell

\begin{tabular}{|c|c|c|c|c|}
\hline \multirow{2}{*}{ Culture } & \multirow{2}{*}{$\begin{array}{l}\text { Oxygen } \\
\text { breathing }\end{array}$} & \multicolumn{2}{|c|}{ Nitrate breathing } & \multirow{2}{*}{$\begin{array}{l}\text { The final } \\
\text { products of } \\
\text { breathing }\end{array}$} \\
\hline & & Denitrification & $\begin{array}{l}\text { Dissimilation } \\
\text { ammonification }\end{array}$ & \\
\hline \multicolumn{5}{|c|}{ Biotope - cathode chamber } \\
\hline Microccocus luteus & + & - & - & $\mathrm{H}_{2} \mathrm{O}, \mathrm{CO}_{2}$ \\
\hline $\begin{array}{l}\text { Staphylococcus } \\
\text { Piscifermentas }[4,5]\end{array}$ & + & - & + & $\mathrm{H}_{2} \mathrm{O}, \mathrm{CO}_{2}, \mathrm{NH}_{4}^{+}$ \\
\hline Paracoccus yeei & + & + & - & $\begin{array}{l}\mathrm{H}_{2} \mathrm{O}, \mathrm{CO}_{2}, \mathrm{~N}_{2} \mathrm{O}, \\
\mathrm{NO}, \mathrm{N}_{2}\end{array}$ \\
\hline Bacillus licheniformis & + & + & - & $\mathrm{H}_{2} \mathrm{O}, \mathrm{CO}_{2}, \mathrm{~N}_{2}$ \\
\hline
\end{tabular}




\begin{tabular}{|l|l|l|l|l|}
\hline Streptomyces hirsutus & + & + & - & $\mathrm{H} 2 \mathrm{O}, \mathrm{CO}_{2}, \mathrm{NO}_{2}^{-}$ \\
\hline $\begin{array}{l}\text { Streptomyces } \\
\text { violaeoruber }\end{array}$ & + & + & - & $\mathrm{H}_{2} \mathrm{O}, \mathrm{CO}_{2}, \mathrm{NO}_{2}^{-}$ \\
\hline $\begin{array}{l}\text { Sphingomonas } \\
\text { paucimobilis }\end{array}$ & + & - & - & $\mathrm{H}_{2} \mathrm{O}, \mathrm{CO}_{2}$ \\
\hline \multicolumn{7}{|c|}{ Biotope - anode chamber } & $\mathrm{H}_{2} \mathrm{O}_{2} \mathrm{CO}_{2}, \mathrm{NO}_{2}^{-}$ \\
\hline $\begin{array}{l}\text { Micrococcus roseus } \\
\text { Bacillus subtilis }\end{array}$ & + & - & + & $\mathrm{NH}_{4}^{+}$ \\
\hline $\begin{array}{l}\text { Sphingomonas } \\
\text { paucimobilis }\end{array}$ & + & - & + & $\mathrm{H}_{2} \mathrm{O}_{2} \mathrm{CO}_{2}$ \\
\hline
\end{tabular}

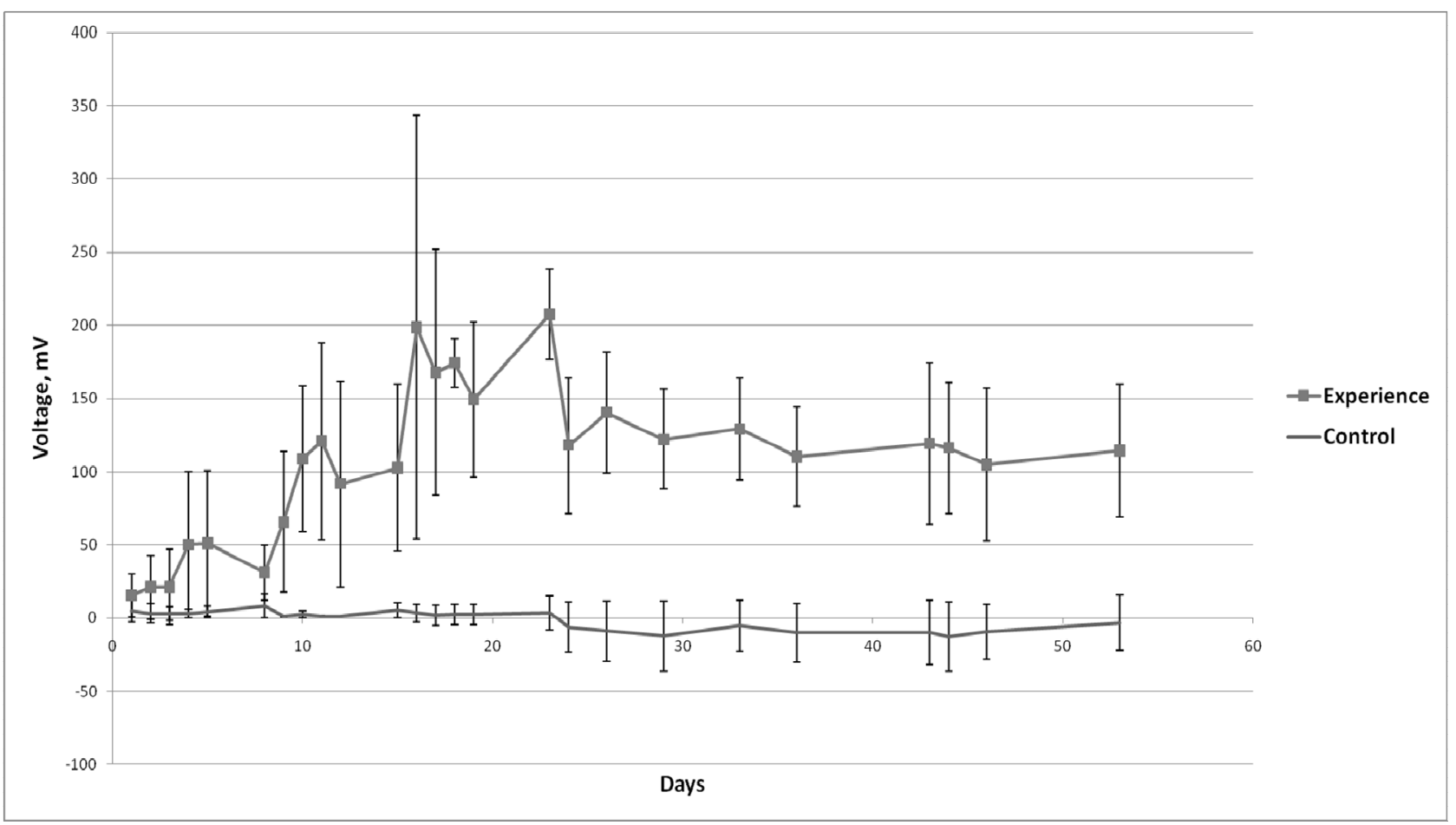

Fig. 4. Dynamics of voltage variation in the external chain of MFC with periodic addition of peptone solution

The values of the output power of cells containing river silt with periodically added peptone are shown in Fig. 4.

It can be seen from the graph that the MFC, into which the peptone solution was added, generated a significantly higher electrical power than the control MFCs. The maximum power values were recorded from the 15 th to the 25 th day of the experiment. The optical density in the samples taken from the experimental MFC also significantly exceeded the control samples (Fig. 5). 


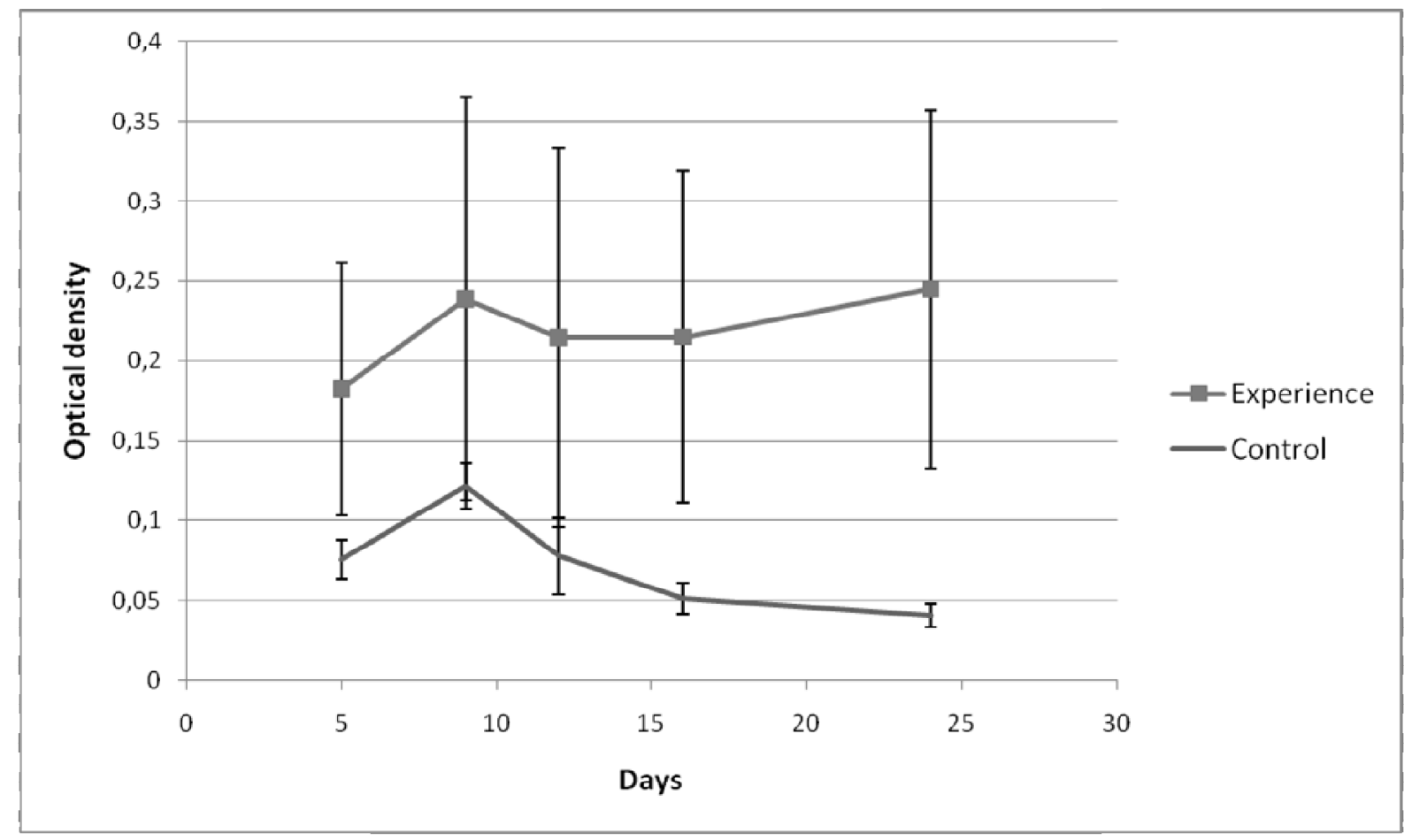

Fig. 5. Dynamics of the change in the optical density of the sludge mass taken from the anode chamber of the MFC, to which a solution of peptone

\section{DISCUSSION}

The results of the microbiological studies presented in Table 1 indicate that the cultures found have a number of common features of energy metabolism. All the bacteria listed in Table 1 are optional or obligate aerobes. Perhaps, therefore, more species have been allocated from the cathode chamber open to air access. However, the presence in the anode chamber of the culture of Sphingomonas paucimobilis, a non-spore-forming, strictly aerobic microorganism, indicates that oxygen was present in the anode chamber at a concentration sufficient for the survival of this bacterium. Anaerobic bacteria gave single colonies, which in the framework of this study can be neglected.

The remaining cultures isolated from MFC have an alternative form of existence in anoxic conditions - nitrate respiration. Such species as Staphylococcus piscifermentas and Bacillus subtilis restore nitrogen to ammonia, decomposing the proteins to peptides and amino acids, which are then utilized by the cell. The process of ammonification is better known as "rotting" [6]. Both cultures were found in the cathode and anode chamber, respectively.

Another, more numerous group of bacteria, is represented by species that restore nitrate to nitrite, nitrogen oxides and molecular nitrogen. Of the seven cultures found in the cathode chamber, four species are capable of denitrification. Such a predominance of microflora with alternative oxygenfree respiration can be explained by competition for oxygen between bacteria, the presence in the biotope of zones with different concentrations of oxygen and substrates with a high content of nitrogenous compounds. Perhaps nitrate breathing is an adaptation to the existence MFC chambers.

The total number of microbial cells: $2 * 10^{5}$ $\mathrm{CFU} / \mathrm{ml}$ and $7.4 * 10^{5} \mathrm{CFU} / \mathrm{ml}$ in the anode and cathode chambers, respectively, which is a difference within one decimal logarithm.

Despite the fact that we did not find anaerobic cultures, their presence in the anode chamber can be assumed based on indirect data: in the control sample, an autoclaved $\mathrm{AS}\left(120^{\circ} \mathrm{C}, 1 \mathrm{~atm} ., 40 \mathrm{~min}\right)$ generated an electric current of relatively low power in the external circuit MFC (Fig. 2 or 3). In the cathode chamber, the number of microbial cells slightly exceeded the analogous index in the anode chamber. However, in the cathode chamber, aerobic bacteria were found to be much larger (Table 1).

The obtained data confirm the legitimacy of the assimilation of MFC flocculine AS.

The evolution of the microbial community of the silt mixture in two directions - in the aerobic and 
anaerobic MFC chambers, apparently leads to the formation of two different communities mutually complementary to each other as part of the MFC and improving the operation of the MFC under the condition of additional dynamic provision (shaking).

Without shaking, the aerobic community of microorganisms that improves the performance of MFC is not formed. Perhaps this is due to the fact that the sludge prevents the access of oxygen to the electrode.

Obviously, in the laboratory version presented here, shaking takes much more energy than can be obtained from MFC. But in this case the fundamental question was solved: is it possible to form an aerobic population of silt microorganisms that improve the performance of MFC. In practice, probably, various technological solutions of dynamic support are possible, allowing to increase the ratio of the received and expended energies in the implementation of the described approach.

Based on the data obtained by adding a solution of peptone to river silt in the MFC, it can be assumed that microorganisms adapted to the use of proteins are an important constituent of the electrogenic microflora of mud masses. Apparently, anaerobic respiration plays a key role in the processes of biological transport of electrons to the anode.

\section{CONCLUSIONS}

1. The data obtained confirm the validity of the assimilation of the MFC flocculine AS.

2. Evolution of the microbial community of the silt mixture in two directions - in the aerobic and anaerobic MFC chambers leads to the formation of two different communities mutually complementary to each other as part of the MFC and improving the operation of the MFC under the condition of additional dynamic provision (shaking).

3. Without shaking, the aerobic community of microorganisms that improves the performance of MFC is not formed. Perhaps this is due to the fact that an unmixed sludge prevents the access of oxygen to the electrode.

4. Regular replenishment of activated sludge with peptone solution significantly increases the electrogenicity of its microflora.

\section{REFERENCES}

1. Debabov, V.G., Production of electricity by microorganisms // Microbiology, 2008, Vol. 77, No. 2, pp. 149-157. (in Russian)

2. Logan B.E. Microbial Fuel Cells, WILEYINTERSCIENCE, 2008, $213 \mathrm{p}$.

3. Nikitina, O.G. Bioestimation: control of the process of biological purification and selfpurification of water. M., 2010, 288 p. (in Russian)

4. Tanasupawat, S.; Hashimoto, Y.; Ezaki, T.; Kozaki, M.; Komagata, K., Staphylococcus piscifermentas sp. nov. from Fermented Fish in Thailand. International Journal of Systematic Bacteriology, 1992, 42 (4): 577-581.

doi:10.1099/00207713-42-4-577

5. Stetina, V., Lauková, A., Strompfová, V., Svec, P., Sedlácek, I., Identification of Staphylococcus piscifermentans from dog feces. Folia microbiologica, 2005, 50 (6): 524-528.

doi:10.1007/bf02931442. PMID 16681152.

6. Gusev, M.V., Mineeva, L.A., Microbiology. Moscow: Publishing Center "Academy", 2003. - 464 p. (in Russian)

\title{
ИЗСЛЕДВАНЕ НА ЕЛЕКТРОГЕННИТЕ СВОЙСТВА НА МИКРОФЛОРАТА НА КАЛНИ МАСИ, ПОЛУЧЕНИ ОТ РАЗЛИЧНИ БИОТИПИ
}

\author{
А.Ю. Тюрин-Кузмин, В.К. Илин, Д.В. Коршунов, А.В. Пунегова, Ю.В. Супрунова
}

Резюме: Микробните горивни клетки (МГК) могат да се използват като средство за получаване на електрическа енергия по екологичен начин, което често се съпътства с разграждане на органични отпадъци. Главен проблем за тези устройства е малката мощност на генерирания електрически ток. В природата разграждането на органични отпадъци, съчетано с окислително-редукционни реакции, т.е. пренос на електрони и протони, образувани по време на разграждането, се извършва от микробни съобщества, които в своето оптимално за този процес състояние се наричат активна утайка (АУ). Зрялата АУ се състои от т.н. флокулуми - кръгли формации с размери от 30 до 100 и повече микрона, в които се съдържат микроорганизми, които осъществяват различни реакции по разлагане на органични вещества. Очевидно е, че конструкцията на МГК е топологично подобна на активния утаечен флокулант. Осъществихме опити за да проверим как присъствието на микроорганизми във водната камера влияе върху производителността на МГК, като запълнихме анодните и катодните камери с една и съща смес от утайки и тестови клетки, като опитните клетки се разклащаха на шейкър с цел да се създадат 
благоприятни условия за образуване на микробни съобщества. Установено бе, че клетката с АУ в двете камери, която се разклаща с помощта на шейкър, с течение на времето генерира най-високо напрежение във външната верига в сравнение с контролните образци. Получените данни потвърждават достоверността на асимилацията на флокулите на АУ от МГК. Еволюцията на микробното съобщество на утаечната смес в две установки - в аеробни и анаеробни МГК камери - очевидно води до образуването на две различни съобщества, взаимно допълващи се като части на МГК и подобряващи функционирането на МГК при условие на допълнително динамично осигуряване (разклащане). Изследван бе и ефектът от добавянето на пептон в анодната камера върху производителността на МГК - периодичното добавяне на пептон значително увеличи изходната мощност на МГК. Очевидно за стимулиране на електрогенната активност на микрофлората на късна анаеробна утайка могат да се използват субстрати с белтъчна природа, представляващи хранителна среда за електрогенните бактерии.

Ключови думи: микробни горивни клетки, биогоривни клетки, активна утайка, флокули, нитратно дишане

\author{
A.Ju. Tjurin-Kuzmin, V.K. Ilyin, D.V. Korshunov, A.V. Punegova, \\ Russian Federation State Scientific Center - Institute for Biomedical Problems (IBMP) \\ 123007 Khoroshevskoye shosse 76a \\ Moscow, Russia \\ E-mails: alturkuz@mail.ru, ilyin@,imbp.ru, shinobi83@mail.ru, chilly_ice@mail.ru
}

\title{
Ju.V. Suprunova
}

All-Russian Scientific Research Institute of Agricultural Biotechnology

127550, Moscow, Timiryazevskaya street, 42

E-mail: julysupr@yandex.ru

(c) (1) All the contents of this journal, except where otherwise noted, is licensed under a Creative Commons Attribution License 